\title{
Comparative Study ofFungal Diversity and Heavy MetalContent in Street Trees in Cairo and RiyadhCities
}

\author{
Ismail M. Ismail, Ahmad K. Hegazy, Tahany M. Abdelrahman, RamyS.Yehia \\ and Ahd A. Abdelsabour* \\ (Department of Botany and Microbiology, Faculty of Science, Cairo University, Giza 12613, Egypt)
}

\begin{abstract}
Biotic and abiotic pollution is threatening the human health in crowded cities. Heavy metals and fungal pollution is increasing in urban environments. This study aims at assessing the efficiency of the two common street trees Ficus nitida and Conocarpus erectus in intercepting heavy metals and fungal aerosols in the air of Cairo and Riyadh cities. The results showed higher levels of heavy metals in air of Cairo than in Riyadh. The fungal species diversity in the two cities increased during summer than in winter season. The highest concentration of $\mathrm{Ni}$ was recorded in Cairo with maximum value in Tahrir site which reached $0.332 \mathrm{mg}$ $\mathrm{g}^{-1}$, while in Riyadh the maximum value recorded in Solimania area $0.0431 \mathrm{mg} \mathrm{g}^{-1}$ for Ni and Cd. Alternatively, the lowest value of heavy metals in summer recorded for Cd reached $0.004 \mathrm{mg} \mathrm{g}^{-1}$ in Maadi area and in Riyadh $0.0012 \mathrm{mg} \mathrm{g^{-1 }}$ in Al-mazar area. The fungal species diversity and counts were variable depending on the climatic factors. Temperature is a major factor affecting the seasonal variations in fungal aerosols, while humidity and wind have minor effect. The air quality in Cairo was found to be more polluted than in Riyadh city.
\end{abstract}

Keywords: Cairo, Riyadh, Heavy metals, Fungi, Species diversity, Ficus nitida, Conocarpus erectus

\section{Introduction}

Atmospheric pollution is one of the major problems in urban environments, affecting human health as well as plants and microorganisms. The air quality and micro climate of urban regions is affected by biotic and a biotic components of the ecosystems. The increased environmental pollution in urban atmosphere including heavy metals and fungal aerosols is related to increased urbanization, traffic, rapid growth of population and expansion of industrial activities [1].Traffic is particularly different from other sources of air pollution because vehicular emissions are readily inhaled by humans due to their close proximity before the atmospheric dilution can affect its concentration. Urban street trees provide many important ecosystem services, such as atmospheric pollution reduction, increased wild biodiversity, and keep human health.

Many previous studies covered heavy metals while biotic pollution received less concerns in arid regions $[2,3,4,5,1]$. Fungal spores are an important part of the atmospheric bioaerosols[6] and they may form up to $45 \%$ of coarse particulate matter [7]. Basidiospores and ascosporesconstitute between $40-100 \%$ of total fungi detected in urban air particulate matter $[8,9]$.The pollution effect contributes directly or indirectly to the human health; basically inhalation of small particles with diameters of $10 \mathrm{~mm}$ or less which absorbed through the human lung causing major health problems. Heavy metals like lead, mercury, copper, cadmium, zinc, nickel, chromium are among the most common pollutants found in industrial emissions which cause serious threat to environment, wild life and human because of their extreme toxicity. Heavy metals pose a health hazards to human. The most common health problem is allergy. People who are sensitive to heavy metals exposure may develop a skin rash somewhat like poison ivy. The rash becomes itchy and may form watery blisters. Once a person gets metal allergy, it remains life time.

The street trees especially the foliage organs are considered fillers for heavy metal pollution and many act as biological filters. This depends on the leaf geometry and surface characteristics such as cuticle, epidermis, stomata and the tricomes[10,11, 12, 13, 14, 15, 16, 17].The micro-environment of the leaf surface hosts different populations of microorganisms. This area was originally named the 'phyllosphere' [18] but is also referred to as the 'phylloplane' [19]. The impact of phyllosphere attached particles is often neglected in studies regarding of the atmosphere $[20,21]$ including their impact on the environment and human health.Urban street trees such as Ficus nitida and Conocarpuserectus act as an efficient biological filters that remove air pollutants in crowded areas. These two species are widely used in arid land cities for provision of shade. They are common street tree species in Cairo and Riyadh cities.The objectives of present study are to:(1)Assess the efficiency of some urban street trees in intercepting fungal aerosols and other physical pollutants such as heavy metals; (2)Assess the fungal composition of environmental aerosols intercepted by urban tree leaves and how it changes overtime and with location; (3)Identification of fungal aerosols in urban atmosphere and their potential risk to human and environmental health; and (4)Study the relationship between heavy metal interception and fungal aerosols interception by urban street trees. 


\subsection{Study area}

\section{Materials And Methods}

Study sites were selected in Cairo and Riyadh cities. Site selection was chosen randomly in every city as based on the potential pollution level. The selected sites in Cairo are located in Helwan, Tahrir square and Maadi, while in Riyadh the sites located in Al-Mazar, Al-Azezia and Solimania (Table 1) for GPS site location.

Table 1Coordinates of the study sites

\begin{tabular}{|c|c|c|}
\hline City & Study site & GPS Location \\
\hline \multirow[t]{3}{*}{ Cairo } & Helwan & $\begin{array}{l}29^{\circ} 50^{\prime} 54.64 " \mathrm{~N} \\
31^{\circ} 19^{\prime} 58.99^{\prime \prime} \mathrm{E}\end{array}$ \\
\hline & Tahrir & 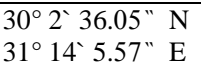 \\
\hline & Maadi & 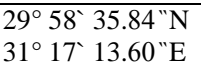 \\
\hline \multirow[t]{3}{*}{ Riyadh } & Al-Mazar & 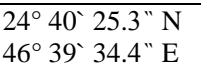 \\
\hline & Al-Azezia & $\begin{array}{l}24^{\circ} 36^{\prime} 29.9^{\prime \prime} \mathrm{N} \\
46^{\circ} 46^{\prime} 16.7^{\prime \prime} \mathrm{E}\end{array}$ \\
\hline & Solimania & $\begin{array}{l}24^{\circ} 42^{\prime} 14.7^{\prime \prime} \mathrm{N} \\
46^{\circ} 42 ` 32.3^{\prime \prime} \mathrm{E}\end{array}$ \\
\hline
\end{tabular}

\subsection{Street trees species}

The Indian laurel (Ficus nitida) is the most common street tree in Cairo. The tree is evergreen that may reaches up to $20 \mathrm{~m}$ height. The leaf ranges between $2-5 \mathrm{~cm}$ long and is glossy, shiny and bright green color. The tree crown has very dense branching and foliage.The buttonwood (Conocarpus erectus) is the most common street tree in Riyadh city. It is fast growing and evergreen with a dense multiple-p trunked tree that can grow up to $20 \mathrm{~m}$ height. The leaf ranges between $2-7 \mathrm{~cm}$ long,but rarely to $10 \mathrm{~cm}$ long and $1-3 \mathrm{~cm}$ broad. Leaves are dark green and shiny on upper surface and paler with fine silky hairs on the lower surface.

\subsection{City climate}

The climate data of the average monthly temperature, rainfall, relative humidity and wind velocity were obtained from the Presidency of Meteorology and Environment, Saudi Arabia in Riyadh and from Ministry of Civil Aviation-Meteorological Authority, Egypt. Data for ten years were averaged for every city.

\subsection{Fungal species}

The phylloplane fungal species were isolated by transferring 10 discs of leave sample into $250 \mathrm{ml}$ conical flask containing $100 \mathrm{ml}$ sterile distilled water, then shaked for $10 \mathrm{~min}$ in shaker at $200 \mathrm{rpm}$. $1 \mathrm{ml}$ aliquot samples of leaf washing were placed in five replicates sterile Petri dishes. 1000ml Czapek-Dox agar was autoclaved and after cooling to- $50^{\circ} \mathrm{C}$, antibiotic was added and mixed thoroughly by shaking. Under aseptic conditions, $20 \mathrm{ml}$ aliquots of such a sterilized solid medium were poured into the dishes and dispersed by gentle rotation. After solidification, the plates were incubated at $27 \pm 1^{\circ} \mathrm{C}$ for 7 days after which the fungal species were purified by subculturing repeatedly on the same medium and identified according to [22, 23], and routinely maintained at $4^{\circ} \mathrm{C}$ on potato dextrose agar (PDA).

\subsection{Heavy metal content}

The concentrations of $\mathrm{Cd}(\mathrm{II}), \mathrm{Cu}(\mathrm{II}), \mathrm{Cr}(\mathrm{II}), \mathrm{Ni}(\mathrm{II})$ and $\mathrm{Pb}$ (II) ions in the samples filtrate from biosorption experiments were determined by using atomic absorption spectrophotometry (AAS, UNICAM-929) with an airacetylene flame at Microanalytical Center, Cairo, Egypt. The instrument calibration was checked periodically by using standard solutions of metal that will be determined. Before measured by AAS, the metal solutions were appropriately diluted with $\mathrm{ddH}_{2} \mathrm{O}$ to ensure the metal concentration in the sample was linearly dependent on the absorbance detected.

\subsection{Species diversity}

The fungal species diversity was determined by Shannon-wiener index $\left(\mathrm{H}^{\prime}\right)$ and calculated as following:

$$
\mathrm{H}^{\prime}=\sum_{i=1}^{g} P i \ln P i
$$

Where $S=$ number of species and $\mathrm{Pi}=$ proportion of the importions $\mathrm{P} 1, \mathrm{P} 2, \mathrm{P} 3, \ldots \ldots . \mathrm{Pn}$. 


\subsection{Climate}

\section{Results}

The average monthly temperature in Riyadh was higher than that in Cairo all the year round with maximum value $37.4{ }^{\circ} \mathrm{C}$ and $28.35{ }^{\circ} \mathrm{C}$ during the months of August and July for Riyadh and Cairo, respectively. The winter temperature ranged from $16.6^{\circ} \mathrm{C}$ to $18.1{ }^{\circ} \mathrm{C}$, and $15.4{ }^{\circ} \mathrm{C}$ to $15.1{ }^{\circ} \mathrm{C}$, while the summer temperate ranged from $27.7^{\circ} \mathrm{C}$ to $28.8{ }^{\circ} \mathrm{C}$, and $21.25^{\circ} \mathrm{C}$ for Riyadh and Cairo, respectively. (Fig.1A). The relative humidity in Cairo was higher than that in Riyadh all year round with maximum value reached $61 \%$ and $50 \%$ during the months of November and December for Cairo and Riyadh, respectively. The winter relative humidity ranged from $60 \%$ to $54 \%$ and $50 \%$ to $35 \%$, while the summer humidity from $49 \%$ to $57 \%$ and $25 \%$ to $20 \%$ for Cairo and Riyadh, respectively. (Fig.1B).

The monthly wind velocity is higher in Cairo with maximum value $14.82 \mathrm{kts}$ in April and $1.30 \mathrm{kts}$ in both February and March. The wind velocity in winter is 11.11 to $13.0 \mathrm{kts}$ and 0.74 to $1.3 \mathrm{kts}$, while in summer the values were 13.0 to $9.26 \mathrm{kts}$ and 1.30 to $0.56 \mathrm{kts}$ in Riyadh and Cairo, respectively. (Fig.1C).The average monthly Rainfall in Cairo was higher in Riyadh than in Cairo with irregular patters of variation around the year. The maximum value recorded $97.8 \mathrm{~mm}$ and $6.5 \mathrm{~mm}$ in December in Riyadh and Cairo respectively. The winter Rainfall was ranged from 97.8 to $8.3 \mathrm{~mm}$ and 6.5 to $3.5 \mathrm{~mm}$, while the maximum summer Rainfall reached 9.2 $\mathrm{mm}$ and $2.4 \mathrm{~mm}$ for Riyadh and Cairo, respectively. (Fig.1D).
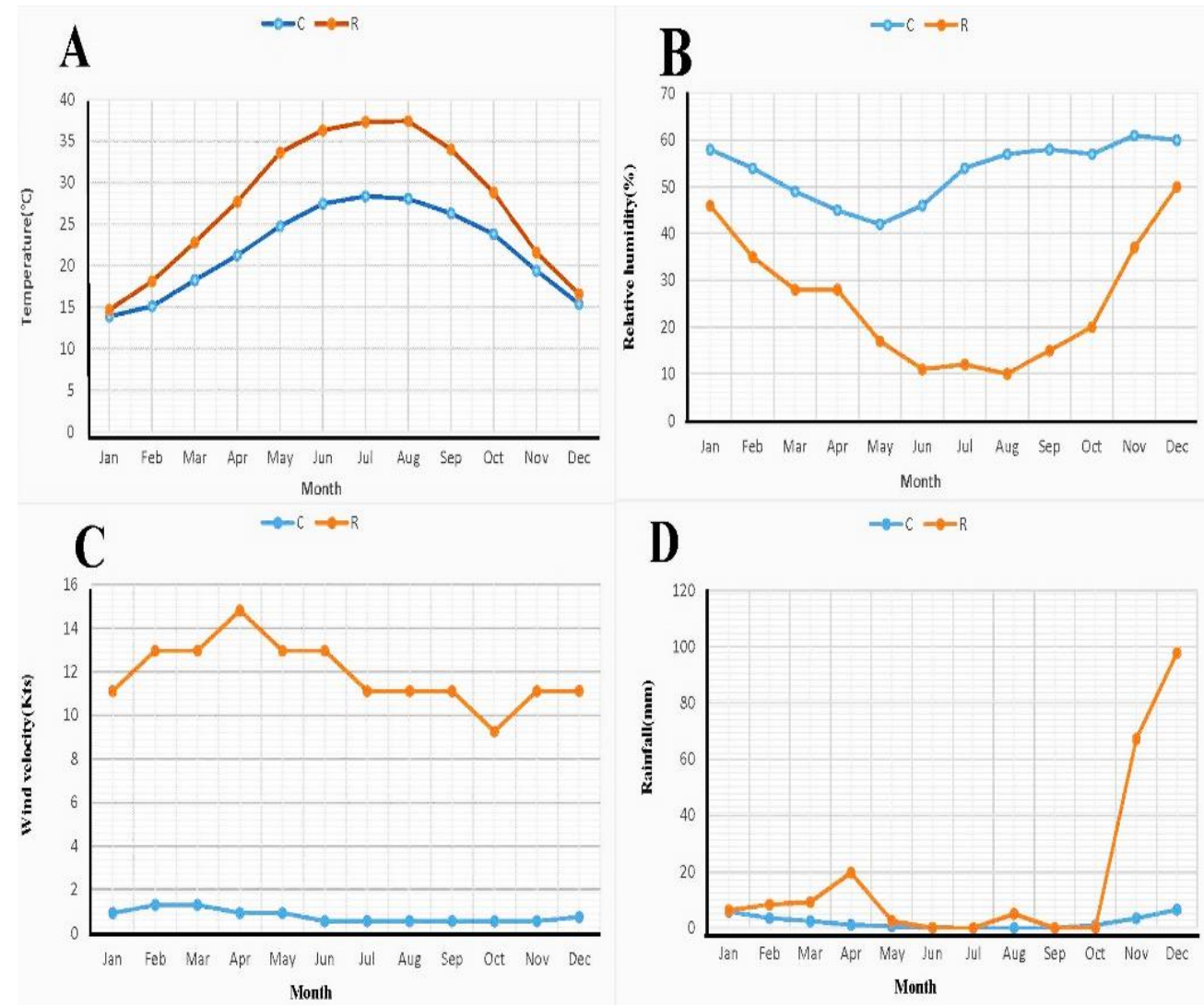

Fig. 1 Mean monthly temperature (A), rainfall (B), relative humidity (C), and wind velocity (D) in Cairo and Riyadh. Error bars represent standard deviations of means.

\subsection{Species diversity}

The fungal species diversity index on leaf surface in summer was higher than in the air in five sites except in Tahrir area where the diversity reached relatively high values. The diversity index values in winter reached 2.215, 2.026 and 2.359 on leaf surface while in air the value reached 1.763, 1.995 and 1.758 in Al-Mazar, AlAzezia and Solimania, respectively. In Cairo the diversity index on leaf surface in winter was 2.708, 1.574 and 1.998, while in the air reached 2.471, 2.476 and 1.619 in Helwan, Tahrirand Maadi, respectively (Fig.2.A, B).

In winter the fungal species diversity was higher on the leaf surface than in the air except in Maadi and AlAzezia areas. In Riyadh the diversity index values were 1.816, 1.895 and 2.142 on the leaf surface and 1.709, 1.956 and 1.515 in the air of Al-Mazar, Al-Azezia and Solimania, respectively (Fig.2C, D). Alternatively in Cairo the values were $2.111,1.654$ and 1.2664 on the leaf and 1.999, 1.645 and 1.506 in the air in Helwan, Tahrir and Maadi, respectively. 


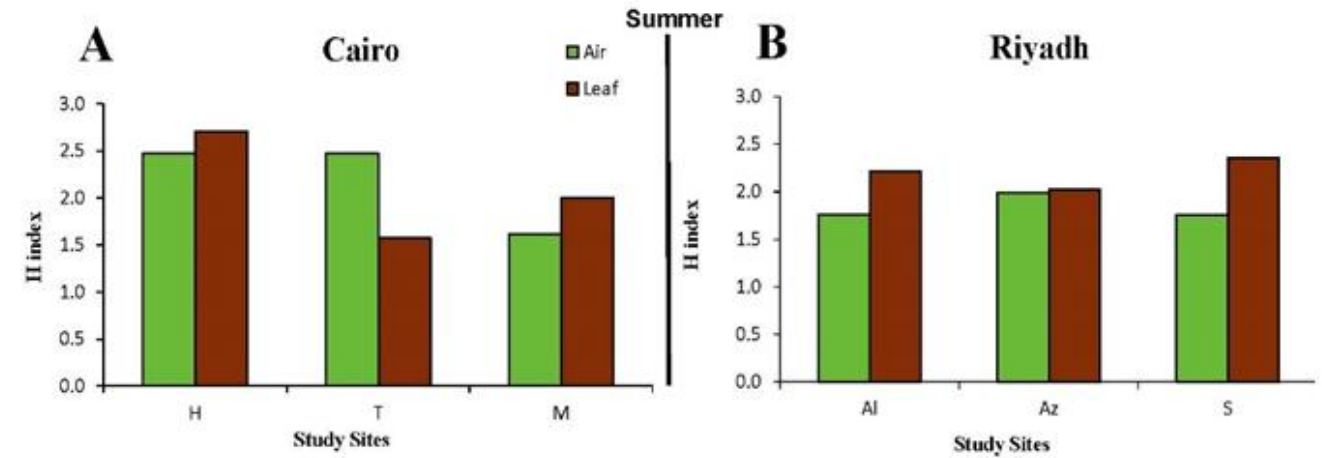

B Riyadh

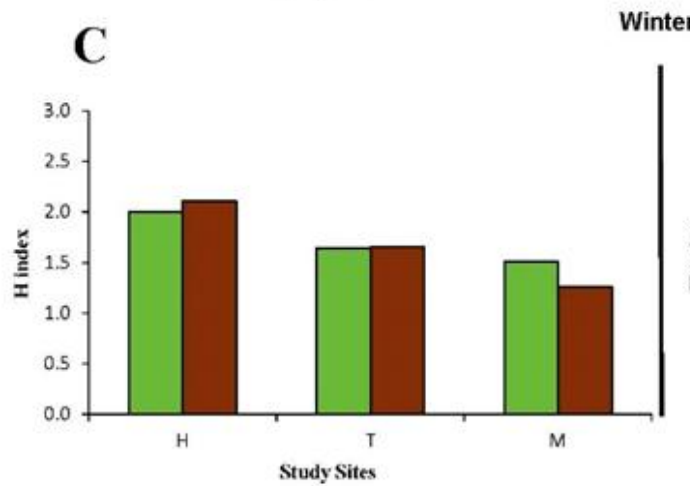

D

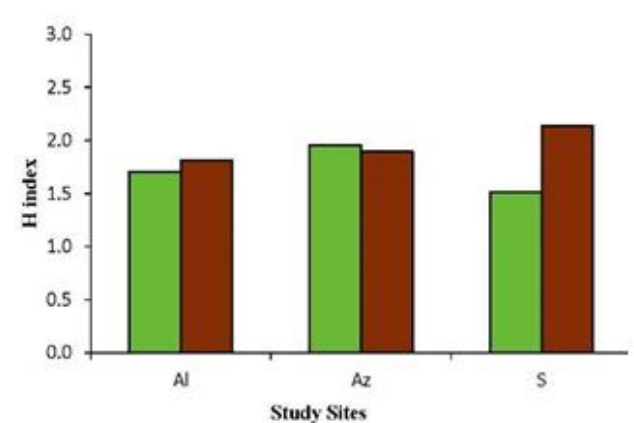

Fig. 2 Shannon's diversity index $(\mathrm{H})$ for fungal species in air and on leaves, in summer and winter, in the study sites.in Cairo H=Helwan, $\mathrm{T}=$ Tahrir, $\mathrm{M}=$ Maadi and In Riyadh Al=Al-Mazar,Az=Al-azezia\& S=Solimania.

\subsection{Leaf heavy metal content}

The heavy metal concentration in plant leaves was higher in Cairo than in Riyadh study sites in summer and winter. The concentration of $\mathrm{Cr}$ and $\mathrm{Ni}$ was higher in Cairo than in Riyadh with values reached 0.23 and $\mathrm{mg} \mathrm{g}$ ${ }^{1}$ for $\mathrm{Cr}$ and $\mathrm{Ni}$, respectively. Lead concentration in leaves was similar in both cities with value $0.13 \mathrm{mg} \mathrm{g}^{-1}$. In general, the heavy metal pollution level was significantly lower in Riyadh than in Cairo as for the season, the pollution was greatly lower in winter than in summer (Fig. $3 \mathrm{~A}, \mathrm{~B}$ ).

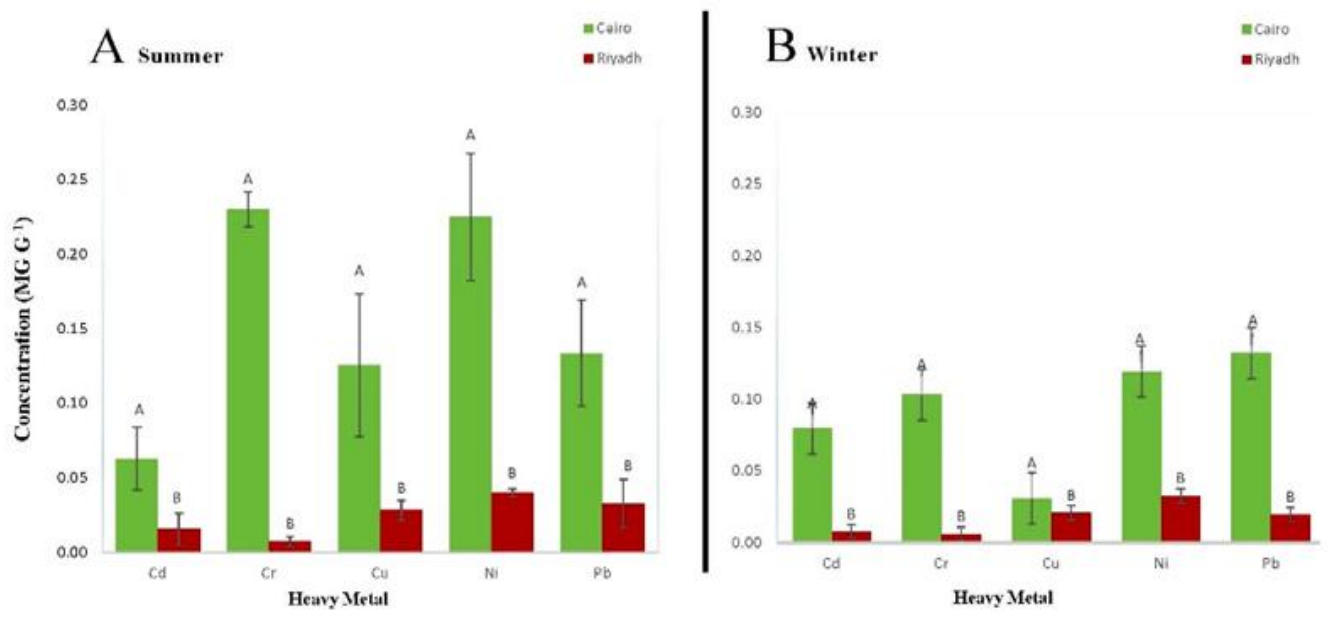

Fig. 3Heavy metal content in Ficus nitida leaf in Cairo and Conocarpuserectusleaf in Riyadh cities. Error bars represent standard deviations of means. Different letters for the same heavy metal represent significant difference of values between Cairo and Riyadh at $\mathrm{P} \leq 0.05 . \mathrm{Cd}=$ Cadmium, $\mathrm{Cr}=\mathrm{Chromium}, \mathrm{Cu}=\mathrm{Copper}, \mathrm{Ni}=$ Nickel and $\mathrm{Pb}=$ lead.

\subsection{Relationship between heavy metal content and species diversity}

The relationship between heavy metal concentration and fungal species diversity in Cairo as shown in (Fig.4) demonstrates both positive and negative relations in the different seasons. In summer, the $\mathrm{Cd}$ and $\mathrm{Cu}$ showed positive relation, while the other two metals showed varied positive and negative relationship between species diversity and heavy metal concentration in plant leaves (Fig.4 A,B,C,D and E). 

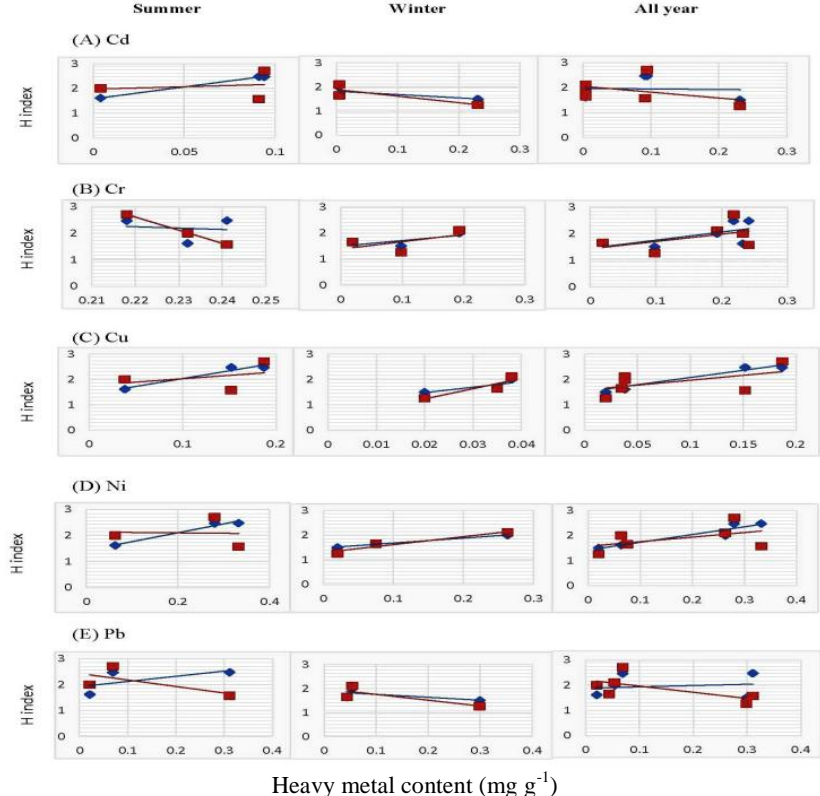

Fig. 4 Relationship between heavy metal content inFicus nitida leaf in Cairo and Shannon's diversity index of fungal species in air (open symbol and dashed trendline) and on leaf (closed symbol and straight trend line).

For Riyadh city, the relationship between species diversity and leaf heavy metal concentration was irregular and variable in summer \& winter (Fig.5). The species diversity on the leaf was higher than in the air in summer and winter. The relationship was slightly different among the levels of heavy metal concentration.Comparing the two cities, the relationship showed concave regressions for $\mathrm{Pb}$ in Cairo and Riyadh, while linear relationship occurs for $\mathrm{Cu}$ (Fig.6). For $\mathrm{Cu}$ in Cairo and Riyadh a convex relationship occurs for $\mathrm{Cr}$ in both Cairo and Riyadh. As for $\mathrm{Cd}$, a convex shape line and linear line for Ni occurs for Riyadh city.

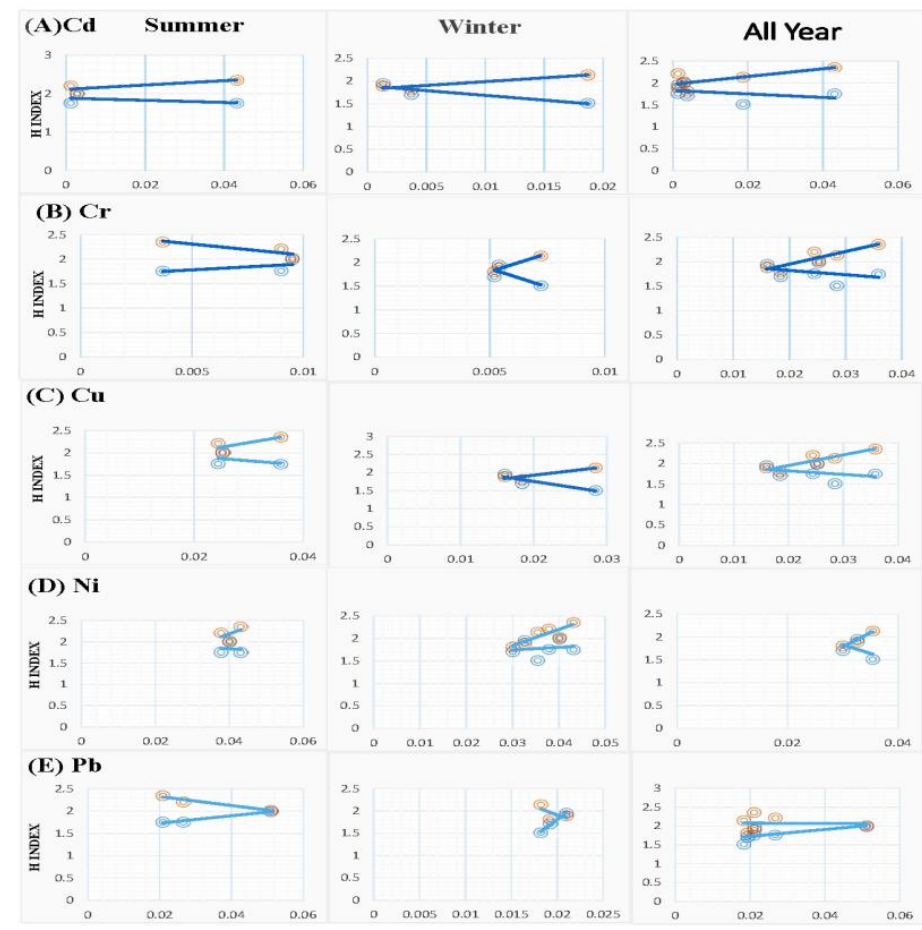

Heavy metal content $\left(\mathrm{mg} \mathrm{g}^{-1}\right)$

Fig. 5 Relationship between heavy metal content in Conocarpuserectus leaf in Riyadh and Shannon's diversity index of fungal species in air (open symbol and dashed trend line) and on leaf (closed symbol and straight line). 

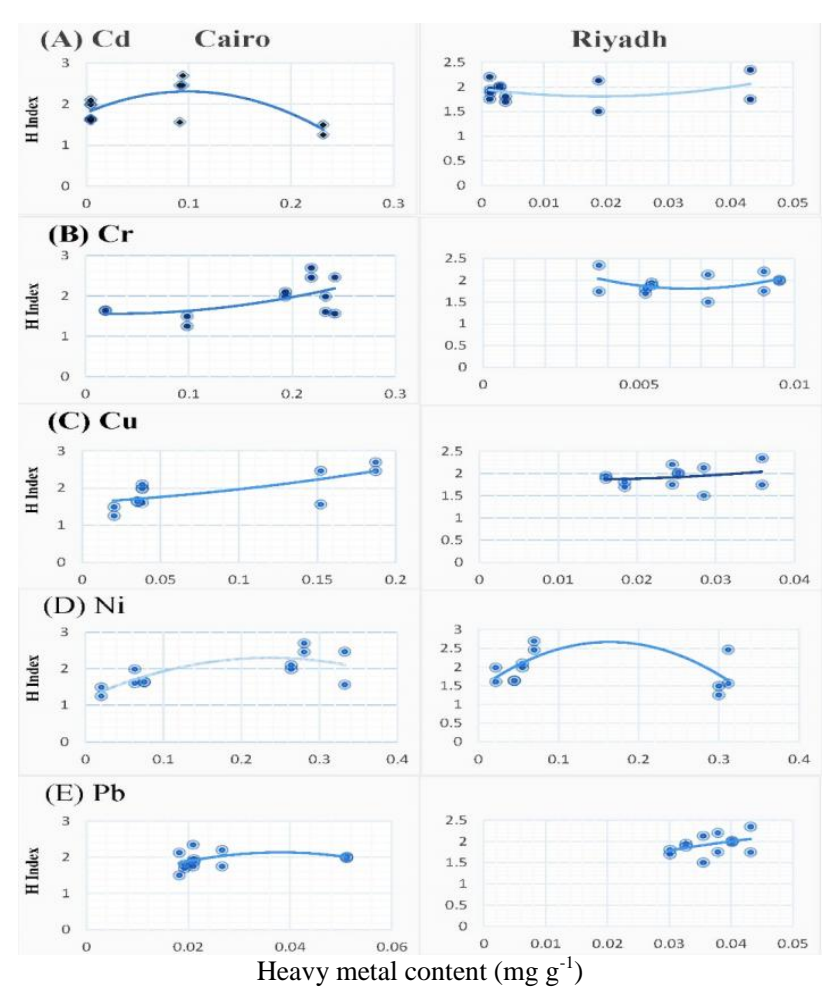

Fig. 6 Relationship between heavy metal content in leaves of Ficus nitida and Conocarpuserectus in Cairo and Riyadh respectively, and Shannon's diversity index of fungal species.

\section{Discussion}

The environmental settings of the study areas showed higher levels of heavy metals pollution in Cairo than in Riyadh. The results showed that fungal species diversity and counts in polluted sites of both cities increased during summer season than in winter. The highest concentration of $\mathrm{Ni}$ was recorded in Cairo with maximum value in Tahrir site which reached $0.332 \mathrm{mgg}^{-1}$, while in Riyadh the maximum value recorded in Solimania area $0.0431 \mathrm{mgg}^{-1}$ for $\mathrm{Ni}$ and Cd. Alternatively, the lowest value of heavy metals in summer recorded for Cd reached $0.004 \mathrm{mgg}^{-1}$ in Maadi area and in Riyadh $0.0012 \mathrm{mgg}^{-1}$ in Al-mazararea. The influence of climatic factors temperature and humidity, for Cairo on the fungal counts aerosols was found to be independent of sampling site, but differed significantly between summer and winters seasons. The fungal concentrations were found to increase with temperature in both cities. The fungal species count was higher in Cairo than in Riyadh, where in summer the count reached 16 and 13 species in Cairo and Riyadh, respectively. Many genera were predominant in both cities including Alternaria,Aspergillus, Penicillium but Aspergillus attained peak count in summer for the two cities. The diversity of fungal species in air and the phylloplane reached the highest value in Cairo 2.7085 and 2.1107 on leaf surface in summer and winter, and 2.4706 and 1.9989 in urban summer and winter, respectively. In Riyadh, higher values were reached in theSolimania area 2.3588 and 2.1416 on the leaf surface in summer and winter, respectively.

The variability of fungal aerosols in urban areas could be related to many other factor such as vehicle traffic, turbulent airflow, amount of suspended dust and density of population [24]. Cu is essential metal for plant growth, but the metal concentration above $20 \mu \mathrm{gg}^{-1}$ reported to be toxic for plants[25]. $\mathrm{Cu}$ in the atmosphere usually comes from fossil fuel combustion and iron steal manufacturing. As for $\mathrm{Pb}$, the major source is car gas fuel.The increased $\mathrm{Cd}$ concentrations in urban atmosphere is related to the accumulation of dust transported by winds and other human activity.In [26] evaluation, the total fungal concentration was found to decrease with temperature in summer and increase in winter, while records showed an increased concentration with relative humidity. This might be related to each microorganismswith its specific sensitivity to environmental parameters, such as temperature, humidity, wind speed and air pollutants. The influence of wind speed as a dilution factor of bioaerosols has been hardly demonstrated in dispersion models [27] and environmental studies [28].On the other hand, the air current may induce bioaerosols into atmospheric environments. In other studies, the strong negative correlation between fungal concentration and wind speed was observed when wind speed was under $5 \mathrm{~ms}^{-1}$, while increased when the speed exceeds $5 \mathrm{~ms}^{-1}[26]$. In other regions, the fungal concentration in air was found to be species specific. For example, in [26] studies showed that the Cladosporium and Alternaria spores attain peak count in Taipei city. Similarly, the same results were recorded in United Kingdom [29], and Canada [30]. The different results might be related to each fungal 
countswith its species sensitivity to environmental factors.In conclusion, the fungal species diversity and counts in Cairo and Riyadh cities are variable depending on the differences in climatic factors. Temperature is the most important factors for the seasonal variations in fungal bioaerosols, while humidity and wind have minor effect as compared to temperature. The air quality in Cairo is found to be more polluted than in Riyadh city.

\section{References}

[1]. EL-Khatib1, A. M. Abd El-Rahman1, O. M. Elsheikh1. (2011). Leaf geometric design of urban trees: potentiality to capture airborne particle pollutants. Department of Botany, Faculty of Science, Sohag University. Journal of Environmental Studies, 7, 4959.

[2]. Iqbal, M., Abdin, M.Z., Mahmooduzzafar, M., Yunus and Agrawal, M. (1996). Resistance mechanisms in plants against air pollution. In: Yunus, M., Iqbal, M. (Eds), Plant Response to Air Pollution. John Wiley, Chichester, 194-240.

[3]. Frost, K., Frank, E. and Maibach, E. (1997). Relative risk in the news media: A quantification of misrepresentation. Amer. J. Public Health, 87, 842-845.

[4]. Markert, B.A., Breure, A.M., Zechmeister, H.G. (2003). Definitions, strategies and principles for bioindication/biomonitoring of the environment. In: Markert, B.A., Breure, A.M., Zechmeister, H.G. (Eds.), Bioindicators and Biomonitors. Elsevier Science, Amsterdam, 3-39.

[5]. Moraes, R.M., Delitti, W.B.C., Moraes, J.A.P.V. (2003). Gas exchange, growth, and chemical parameters in a native Atlantic forest tree species in polluted areas of Cubatao, Brazil. Ecological and Environmental Safety, 54, 339-345.

[6]. Sesartic, a., \&Dallafior, T. N. (2011). Global fungal spore emissions, review and synthesis of literature data. Biogeosciences, 8(5), 1181-1192.

[7]. Frohlich-Nowoisky, 1. Pickersgill, D. A., Despres, V. R., \&Poschl, U. (2009). High diversity of fungi in air particulate matter. Proceedings of the National Academy of Sciences of the United States of America, 106(31), 12814-12819.

[8]. Despres, V. R., Nowoisky, 1. F., Andreae, M. 0. Klose, M., Conrad, R., \&Poschl, U. (2007). Characterization of primary biogenic aerosol particles in urban, rural, and high-alpine air by DNA sequence and restriction fragment analysisof ribosomal RNA genes. Biogeosciences, 4(6), 1127-1141.

[9]. Wu, Y. H., Chan, C. C., Rao, C. Y., Lee, C. Te, Hsu, H. H., Chiu, Y. H., \& Chao, H. J. (2007). Characteristics, determinants, and spatial variations of ambient fungal levels in the subtropical Taipei metropolis. Atmospheric Environment, 41(12), 2500-2509.

[10]. W Barthlott, C Neinhuis, D Cutler, F Ditsch, I Meusel. (1998). Classification and terminology of plant epicuticular waxes. Botanical Journal of the Linnean Society, 126 (3), 237-260.

[11]. Beckett, K.P.; Freer-Smith, P.H.; Taylor, G. (1998). Urban woodlands: their role in reducing the effects of particulate pollution. Environmental Pollution,99 (3), 347-360.

[12]. El-Khatib, A. A. (1999), 'Environmental management and impact assessment of Al-Kawther industrial zone of the flora within and enclosed surrounding areas', in Proceeding of the International Conference on Environmental Management, Health and Sustainable Development, Alex. Egypt 22-25 March.

[13]. El-Khatib, A. A. (2002), 'Trapping of atmospheric heavy metal pollutants by leaves of urban trees in arid environments', Tech . Report.

[14]. El-khatib, A.A. and Elswaf N. (2001). Physiotoxicity of air particulate Pollutants (Dust) and the growth of urban treesFicus nitida. Bulletin of Faculty of Science, Assiut University, 30, 183-193.

[15]. Sawidis, T., A. Marnasidis, G. Zachariadis and J. Stratis. (1995). A study of air pollution with heavy metals in Thessaloniki city (Greece) using trees as biological indicators. Archives of Environmental Contamination and Toxicology, 28, 118-124.

[16]. Al-Shayeb, S.M., Al-Rajhi, M.A., Seaward, M.R.D. (1995). The date palm (Phoenix dactylifera L.) as a biomnitor of lead and other elements in arid environments.TheScience of the Total Environment, 168 (1), 1-10.

[17]. Due, M., Kreeb, K. H. (1993). Seasonal variations of foliar metal content in three fruit tree species. In: Markert B., editor. Plant as biomonitors / indicator for heavy metals in the terrestrial environment. Weinheim: VCH Publisher, 577-592.

[18]. Seaward, M.R.D. and A.M. Mashhour. (1991). Oleander (Nerium oleander L.) as a biomonitor of heavy metal pollution. In: Urban Ecology M.A. Ozturketa.l (eds), Ege University Press, Izmir, Turkey, 48-61.

[19]. Windels, C. and S. E. Lindow. (2003). Microbiology of the Phyllosphere, Applied and Environmental Microbiology, 69, $1875-1883$.

[20]. Inacio, J., Pereira, P., De Carvalho, M., Fonseca, A., Amaral-Collaco, M. T., \& Spencer-Martins, 1. (2002). Estimation and diversity of phylloplanemycobiota on selected plants in a Mediterranean-type ecosystem in Portugal. Microbial Ecology, 44(4), 344-353.

[21]. Elbert, W., Taylor, P. E., Andreae, M. 0. \&Poschl, U. (2007). Contribution of fungi to primary biogenic aerosols in the atmosphere: active discharge of spores, carbohydrates, and inorganic ions by Asco- and Basidiomycota. Atmospheric Chemistry and Physics Discussions, 6(6), 11317-11355.

[22]. Morris, C. E., Sands, D. C., Bardin, M., Jaenicke, R., Vogel, B., Leyronas, C., Psenner, R. (2011). Microbiology and atmospheric processes: Research challenges concerning the impact of airborne micro-organisms on the atmosphere and climate. Biogeosciences, $8(1), 17-25$.

[23]. Gilman, J. C. (1957). A manual of soil fungi. 2nd Ed. Ames, U.S.A.,Iowa State College Press.

[24]. Watanabe, T. (2002). Pictorial Atals Of soil and Seed Fungi: Morphology of Cultured Fungi and Key to Species,2nd end pp.486.Boca Raton, Florid CRC press.

[25]. Giorgio, C. D., Krempff, A., Guiraud, H., Binder,P., Tiret, C., and Dumenil, G. (1996). Atmospheric Pollution by Airborne Microorganisms in the City of Marseilles. Atmospheric Environment, 30, 155-160

[26]. Nriagu, J.O. (1979). Copper in the Environment. Chichester, Willey Interscience

[27]. Lin, W.-H., and Li, C.-S. (2000). Associations of fungal aerosols, air pollutants, and meteorological factors. Aerosol Science and Technology, 32, 359-368.

[28]. Lighthart, B., and Kim, J. (1989). Simulation of airborne microbial droplet transport. Applied and Environmental Microbiology, 55, 2349-2355.

[29]. Pasanen, A.-L., Pasanen, P., Jantunen, M. J., and Kalliokoski, P. (1991). Significance of air humidity and air velocity for fungal spore release into the air. Atmospheric Environment, 25 (2), 459-462.

[30]. Hirst, J. M. (1953). Changes in Atmospheric Spore Content: Diurnal Periodicity and the Effects of Weather.Transactions British Mycological Society, 36, 375-392.

[31]. Li, D.-W., and Kendrick, B. (1995). A year-round outdoor aeromycological study in Waterloo, Ontario, Canada. Department of Botany, University of Waterloo, Grana, 34, 199-207. 